\title{
From Strategic Partnership to Strategic Interdependence: The Pak-China Duo
}

\author{
Namra Naseer \\ PhD Scholar \\ Bahria University - Islamabad. \\ namra0910@gmail.com \\ $\&$ \\ Dr. Azhar Ahmad \\ Senior Associate Professor \\ Bahria University - Islamabad. \\ azhar.buic@bahria.edu.pk
}

\begin{abstract}
China and Pakistan are frequently touted as "strategic partners" based on the historic journey that has fused both states in a resilient partnership. The bilateral relationship is multisectoral based on diplomatic, defence and socio-economic cooperation. If focus of the bilateral ties is to be pinpointed, it would be defence and security cooperation that has been the defining factor of the relationship. However, the equation transformed with the transformation in the geopolitical context of the South Asian region post-2011. Pakistan signed a major economic venture with China; the China Pakistan Economic Corridor besides opening up to Russia as well. After the launch of CPEC in 2015, the defence centric bilateral relationship between Pakistan and China changed into a mega economic partnership. The paper has attempted to understand this transformation between the two countries and make a case for "strategic interdependence" rather than strategic partnership. Since, interdependence takes a deeper meaning than partnership.
\end{abstract}


Key words: Pakistan, China, Sino-Pak, CPEC, Partnership, Strategic Interdependence.

\section{INTRODUCTION}

Pakistan and China have shared an unparalleled bond since their inception. Both countries share a history of cultural and trade links. The bond of friendship in contemporary times has taken a more nuanced outlook. Traditionally driven by defence and security cooperation, the bilateral relationship entered a mega economic partnership in 2015 with the initiation of CPEC. CPEC is one of six corridors of China's larger Belt and Road Initiative (BRI). China's vision of BRI far exceeds the economic domain and must be viewed strategically as well. CPEC can be considered as a litmus test for various other projects under BRI. It is imperative to note economic cooperation between the two countries was nothing compared to the investments made under CPEC. Therefore, the project itself can be denoted as a reason for major transformation in the bilateral ties. CPEC, if studied in detail, also reiterates the strategic relevance of the bilateral relationship for both states. Pakistan needs China's diplomatic, defence and economic support as much as China needs Pakistan for successful completion of BRI. The factor of reliability both states attach to each other must not be ignored as well especially the added advantage of being a neighbour. Similarly, in geopolitical context, Sino Pak relations counterbalance the Indo US nexus in the region. The paper looks deeper into the bilateral relationship and suggests policy reconsideration by Pakistan to view China not just as strategic partner but from the lens of strategic interdependence to leverage its position in a mutually beneficial way.

\section{HISTORICAL CONNECTIONS}

Chinese civilization is known to be one of the oldest civilizations of the world that had many dynasties. Even contemporary security strategy and foreign policy is considered to be drawn from conventional Chinese wisdom. China viewed itself as the "Middle Kingdom" and foreigners as "Barbarians". Therefore, it took China some time to open itself to the world and that happened in the Han Dynasty. During seventh century BC, Chinese travellers started to travel to other parts of the world (Economy, 2017). As China opened more towards the world, the spread of religion 
inside China started to gain momentum. Islam and Buddhism grew gradually. Buddhist pilgrims from China travelled through expeditions to Northern India (today's Gilgit region of Pakistan). These religious linkages consequently enabled China to expand its cultural, economic and religious ties with other regions (Mahdi, 1986).

One interesting similarity was observed between Chinese art and the Gandhara art of Pakistan. Chinese art is believed to be inspired by Gandhara art. Pakistan and China also shared trade linkages in the past through old silk route. It was these trade connections that also played a significant role in connecting China with Bangladesh (Mahdi, 1986). Slowly and gradually these connections grew stronger. These patterns from the past show the demographical connectedness between Pakistan and China.

\section{THE EARLY PHASE OF BILATERAL RELATIONS}

To understand contemporary dynamics between Pakistan and China, it is pertinent to analyse the early phase of the bilateral relationship. Pakistan and China established their diplomatic ties in 1951 after Pakistan became the first Muslim and third non-communist country to recognize People's Republic of China in 1950 (Azeemi, 2007). Since then, both states have maintained cordial ties with each other and have supported each other at regional and international platforms especially the UN. In 1955, Chinese Premier Zhou Enlai and Pakistan Prime Minister Mohammad Ali Bogra had their first meeting during the Bandung (Afro-Asian) Conference. This meeting laid the foundation for promoting understanding and establishing friendly relations between the two states (Azeemi, 2007). Pakistan at this time had joined South East Asian Treaty Organization (SEATO) and Central Treaty Organization (CENTO); the Western military alliances, that raised concerns in Beijing. Utilizing the opportunity of Bandung Conference, Mohammad Ali Bogra assured Zhou Enlai that Pakistan will refrain from becoming part of any actions against China. In 1961 Pakistan voted for a bill regarding restoration of China's legitimate rights in the United Nations. In January 1963, China and Pakistan signed their first trade agreement (How Economic \& Political Tensions Impact the Sino-Pakistani Relationship, 2019). Same year, another important agreement was signed on the basis of the ten principles as articulated in Bandung 
Conference delineating their boundary (The Boundary Agreement Between China and Pakistan, 1963). Gradually leaders from both states started to exchange visits frequently.

In 1965, during Pakistan-India war, while the US turned its back on Pakistan and imposed an arms embargo, China not only supported Pakistan politically but also militarily and logistically (Weinraub, 1974). Disappointed by the US, Pakistan was compelled to find an external balancer against India. China already had a war with India in 1962. In the aftermath of both wars, Pakistan and China shared a common sense of regional security and realized the mutual need to counter threats posed by the Soviet Union and India. Again, during Pak-India war of 1971, it was China that stood by Pakistan. Both countries throughout this time period was concomitantly collaborating in multiple sectors. Karakoram Highway (KKH) was an important project in enhancing trade and communication links between the two countries. Similarly, the creation of Joint Committee of Economy, Trade and Technology in 1982 served as a significant development in enhancing the strategic partnership. Another defining factor of Sino-Pak friendship was in the defence domain; the Comprehensive Nuclear Cooperation Agreement that was signed in 1986. Consolidating defence ties, in 1999 a contract to jointly develop and produce JF-17 Thunder aircrafts was signed; JF-17 were then inducted in Pakistan Air force in 2010. China and Pakistan have cooperated in energy sector as well. In 2000s China also invested in development of Gwadar port and Makran Coastal Highway (Chronology-Main Events in Chinese-Pakistani Relations, 2006).

With Premier Zhu Rongji's visit to Pakistan in 2001, 50 years of establishment of diplomatic ties was celebrated. By this time, both states had developed a fair sense of trust between them. The bilateral relationship continued to flourish on a consistent pace. In 2003 Preferential Trade Agreement was signed followed by the Treaty of Friendship in 2005. The treaty is pivotal as it restricts both states to participate in any bloc or alliance that negatively affects the security, sovereignty and territorial integrity of the other. A clause that was also included in the treaty restricted the use of either's territory against the other by any third party (Khursheed et al., 2019). 
If initial cooperation between the two states is analyzed, it is evident that the central focus of the bilateral ties remained security and defence sector. Even the political and economic cooperation served security and defence purposes. However, over the years various agreements signed between the two countries and mutual support solidified the bond between them and gave the bilateral equation a "sense of reliability". It is significant because in International Relations usually the pragmatism of Lord Palmerston is followed: "no permanent friends, no permanent enemies, just permanent interests" (Panganiban, 2017). This reliability factor is unique to Sino-Pak bond which differentiates it from other relationships. Despite having differences in government structures, cultures and even belief systems, the relationship not only flourished but also endured challenges of dynamic geopolitical milieu. Since beginning of the diplomatic ties, the bilateral relationship between China and Pakistan has evolved through mutual support in multiple sectors: corporate administration, security, political, diplomatic and economic. The relationship remained crucial for both states irrespective of changes in leadership/ government (Siddique, 2014).

\section{POST-2011 GEOPOLITICAL CONTEXT AND FALTERING PAK-US RELATIONS AS A STIMULUS}

It was in 2011 when Pakistan and the United States, often hyped as "strategic allies" witnessed the lowest point in their bilateral relationship. Back to back events like Salala incident, Raymond David case, Abbottabad operation completely tarnished the trust and reliability in the relationship. It was during this time that Pakistan decided to further strengthen its bond with China. During the following years, Pakistan and China expanded their bilateral ties. The previously defence centric relationship entered into a mega economic partnership which was previously less visible (Azeemi, 2007).

The reason behind was CPEC, the one of six corridors under China's BRI. China Pakistan Economic Corridor is an economic venture of its own kind. The economic relations between both countries previously remained low key as compared to the security and diplomatic ties. It is also significant because Pakistan launched Zarbe-Azb in 2014 and both countries signed CPEC in 2015. Pakistan's efforts in countering terrorism in the country complemented with China's interest to invest 
in Pakistan. Similarly, it can be viewed as China's interest in Pakistan became a reason for increasing Chinese help to Pakistan against terrorism (Ibrar et al., 2016). Pakistan Russia rapprochement is also a major development in post 2011; China can be considered as a facilitating factor (Siddiqi, 2017).

The Growing Interests: From Defence Centric Partnership to Geo-Economic Interdependence

The growing Chinese interests in Pakistan can be well elucidated by several domestic as well as external factors. China adopted an economic model labelled, "Socialism with Chinese characteristics" that shifted from a centrally planned system to a market-oriented economy making it possible for China to re-orient its foreign policy along with a strengthened economy to carve a position in the comity of nations. Concurrently, terrorism has reduced gradually in Pakistan and it is just security wise viable for China to consider expanding its economic terms with Pakistan. The Chinese workers in Pakistan also witness a favorable security condition (Faisal, 2020). Pakistan is playing its role and has created conducive environment regarding the Chinese investments at home. China is fully committed and is investing its economic and political energy to make the China-Pakistan relationship mutually beneficial. Pakistan is also conscious about the prospective benefits. Pakistan has proved to be a tried and tested partner of China and is thus, viewed as a credible state to serve as an example for other countries partnering in the BRI. In this regard CPEC can be considered as a litmus test for encouraging other countries to connect with China under its Belt and Road Initiative. China shares multiple economic relations with many countries even with hostile countries but in understanding Sino-Pak relations the element of reliability should not be ignored which is unique factor to the bilateral relationship (Toor, 2017). Pakistan too realizes the potential economic and strategic benefits by collaborating with China. Pakistan's economy has been unstable for a considerable time and lack of foreign direct investment made it even worse. In the foreign policy domain, Pakistan learned many lessons in post 2011 context. The constant demands by the US and its undue support and military assistance to India have generated mistrust between Pakistan and the US. Pakistan understands the transactional nature of its relations with the US and hence, significance of having another strong ally at its side. 


\section{CPEC: Redefining the Nature of Sino-Pak Relationship}

Chinese President Xi Jinping visited Pakistan in April 2015 and announced an economic and trade corridor with Pakistan; the China Pakistan Economic Corridor. This project can be considered as the flagship project that led to the transformation of the nature of the bilateral relations. The decision came when the rising China unlike before had started to get more involved in the regional as well as global politics and China's policy outlook became more reliant on economic cooperation (Hussain, 2017). The debates regarding the pros and cons of CPEC under BRI have surfaced from time to time. Along with the potential of the project, speculations within Pakistan and in other countries have also grown.

The security and defense ties between China and Pakistan served as a stimulating factor for both states to open to economic endeavors. Though CPEC is just one corridor out of six under China's BRI however, it is one of the most crucial ones and amiable relations with Pakistan makes it easier for China to achieve its goals in the region. Pakistan too, considers this opportunity vital for redirecting its economy towards industrial sector. The project is exemplary to be the largest inflow of foreign capital in the country. The investment under CPEC is double the combined economic and military aid provided to Pakistan by the US since 2001 in the wake of global war on terror. The Chinese Foreign Direct Investment (FDI) in Pakistan witnessed an upsurge after CPEC and China emerged as the single largest investor in December 2019 with an investment of \$328.3 million (Hussain, 2017).

Pakistan's economy has witnessed a growth at the average rate of $4 \%$ but is expected to witness an elevation by $2 \%$ in its GDP as an outcome of CPEC ("How Economic \& Political Tensions Impact the Sino-Pakistani Relationship", 2019). These trends indicate that if CPEC is completed successfully, Pakistan will not only have economic stability but will be able to sustain it as well (Menhas et al., 2019). For China, the stakes attached with BRI are much greater and strategic in nature. China intends to yield considerable political gains from BRI such as expansion of its export markets, promotion of Renminbi (RMB) as an international currency and decrease of trade resistances like tariffs and transport costs etc. It solves the "Malacca Dilemma" for China. Also naturally, economically linked states with China will be under its influence and may likely align their policies with Chinese 
interests. The locations opted for BRI and especially CPEC are strategic in nature and give China an edge over other major powers. China in other words, capitalised on its existing strategic relations with Pakistan. It is also imperative to highlight that the contemporary international politics are no longer just driven by military alliances and preponderance but now economy is as much pivotal ("How Will the Belt and Road Initiative Advance China's Interests?", 2017). CPEC can encourage other states to collaborate with China and its success will alleviate reservations of other participatory countries as well. The trouble-free successful completion of BRI projects is vital to claiming the accomplishment of its development model as a rising global power.

China, while opening a gateway to multiple opportunities through CPEC, demands internal stable security situation in Pakistan and in the region, which converges Pakistan and China's counter terrorism efforts. The pros of the project are adequate to propose that China and Pakistan are on a much higher level of bilateral ties than ever before (Malik, 2017). There are hiccups in the process being faced by both states such as the US' reservations and attempts to halt the project, IMF setting conditions for Pakistan, threat from non-state actors and speculations within Pakistan and China (Gopi, 2020). During 2019, the progress on CPEC had been in full swing and focus was laid on the development of Special Economic Zones in Pakistan. Nine SEZs have already been prioritized under second phase (Khan, 2017). It is yet to be seen how CPEC and China-Pakistan relations will overcome these hurdles once the COVID-19 situation settles (Siddiqi, 2020).

CPEC (BRI) can be comprehended as manifestation of China's interest to attain its geostrategic goals through economic means. It makes perfect sense in changing nature of international relations of today. This, however, does not reflect that other sectors in the bilateral relationship are or will be neglected. In fact, CPEC provides a stimulus to deepen security, political and cultural ties as well. Meanwhile, Pakistan is supporting China's rising status of a global power despite being constrained by its strategic compulsions. China reciprocates by reinforcing Pakistan's national interests while still maintaining its neutrality which was apparent through many instances of clash between Pakistan and India. 
Post CPEC deal, China has supported Pakistan's entry into Nuclear Suppliers Group (NSG), resisted Indian-backed proposal to place Masood Azhar on UN terrorists' list and concluded a US\$5 billion deal of selling eight submarines to Pakistan. The deal is noteworthy because it enables Pakistan to augment its nuclear triad (Sattar, 2015). Four out of eight submarines are expected to be delivered by 2023 and rest four by 2028 ("Pakistan - Hangor - Type 41 Yuan-Class New Submarines", 2017).

\section{SOUTH ASIA'S STRATEGIC CALCULUS SERVING AS GEO- ECONOMIC CONVERGENCE}

Pakistan and China previously perceived each other as a strategic hedge to curb India's influence in the South Asia region. Though, it has not diminished but this notion preoccupied the focus of the bilateral terms. The relationship hardly grew into the economic domain. However, this has changed now. The Indian factor remains a converging area for China and Pakistan. Similarly, situation in Afghanistan has also been an imperative feature of South Asia's security order and is another area of convergence between Pakistan and China's interests.

The Indian Factor

The uncertain situation and prolonged unresolved conflicts between Pakistan and India thwart any attempts for cooperation among the two states. To have a complete understanding of the bilateral relations between China and Pakistan, analyzing Indian factor is vital (Chandra, 2016). The new projects and engagements reflect that Pakistan has more expectations from its all-weather friend China vis-a-vis its rivalry with India. However, China sees India from a different lens. China has at times retained its neutrality in various events of clash between Pakistan and India. China does not want to sabotage its economic relationship with India, it is a cause of disappointment for Pakistan (Faisal, 2018). India is also inclusive of BRI via Bangladesh-China-India-Myanmar Corridor (Afridi \& Bajoria, 2010).

Indian government has voiced apprehensions regarding the route of CPEC which crosses through the region of Gilgit Baltistan, which it views as a disputed area. 
China, however, has attempted to address the Indian concerns by assuring that the economic developmental projects do not change the formal standings of the states over disputed territories. Having India onboard for achieving stability in the region is significant for China. China's continuous emphasis on achieving peace and stability in the region depicts how its economic interests are dependent on the security condition of South Asia. The lack of stability and peace in the region can hinder the effectiveness of BRI (Afridi \& Bajoria, 2010). The attainment of strategic balance vis-à-vis India and achieving regional stability go hand in hand for China and Pakistan (Zeb, 2014).

\section{Afghanistan as a Lynchpin for China}

The bilateral relationship between China and Pakistan is also influenced by the prevailing political and security situation in Afghanistan (Zeb, 2014). To have stable Afghanistan and Pakistan is in the strategic and economic interest of China. China through economic development and counter-terrorism efforts aims at stabilizing the chaotic Xinjiang region which shares its border with Pakistan and Afghanistan. Though the United States and the Taliban signed an agreement, but the prospects of stable Afghanistan are still minimal because the probability of domestic clashes between various factions has amplified (Brahma, 2018).

China's interest in Afghanistan has grown gradually (Rahman, 2007). China has made multiple efforts to resolve the Afghan conflict and has been engaged in making arrangements for peace talks since 2014. China's recommendation in October 2014 for establishing a "peace and reconciliation forum" depicts its seriousness. In 2016, China indicated clearly that it aims at enhancing Pakistan's economy by investing in various sectors under the CPEC, but it also considers a stable and secure Pakistan as a prerequisite for investments. Alongside Afghanistan and the United States, Pakistan and China also became members of Quadrilateral Coordination Group (QCG) in 2016 in order to initiate peace talks between the Afghan Taliban and the Afghan government (Javaid \& Javaid, 2016). The respective initiative plays a significant role as China and United States both being the G-2 were a part of the process. Such developments illustrate China's increased desire in stable Afghanistan. China along with Afghanistan and Pakistan had also initiated a trilateral dialogue for the stability in Afghanistan (Chaudhri, 1986). 
A stable and peaceful Afghanistan is in the interest of both, China and Pakistan (Brahma, 2018). China is willing to seek and explore avenues in Afghanistan in order to expand its CPEC project under BRI. All such steps taken by the Chinese government reflect how crucial Afghanistan is for the bilateral relationship between China and Pakistan. Afghanistan is viewed as a lynchpin for China to connect the regions of Central Asia, East Asia and South Asia under its flagship project BRI (Fazl-e-Haider, 2020).

The Areas Overlooked: Weak Links in the Relationship

1. Administrative Issues: Like every other business partnership, CPEC collaboration between Pakistan and China also faces some challenges. From administrative issues to dealing with huge sum of investments, Pakistan's government needs professional management structures which can deal with issues specific to administrative processes and management. Furthermore, as the CPEC foresees investments in several sectors of Pakistan, there is a need by Pakistan to provide and involve efficient and smart managers which are trained in quick and effective decision-making processes so that the bureaucratic barriers can be minimized (Small, 2015).

2. Inconsistent Policies: Since the implementation of $18^{\text {th }}$ Amendment, Pakistan's provincial governments have been given a right to have their say in matters regarding economy; a backdrop is the lack of cohesion and consistency between policies. It has become necessary to achieve better cohesion between the federal and provincial bureaucracies and also the policymakers, for the improved management of CPEC. Hiccups in development of Special Economic Zones (SEZs) is a prominent example. Institution of CPEC Authority is a good step in this direction.

3. Cultural Diffusion: With the execution of CPEC project, the learning and understanding of both the cultures by its people is equally important. While cultural understanding is important, both states must be wary of consequences of cultural diffusion. 


\section{Deficiency of People to People Contact and Socio-Cultural Linkages:}

One of the major gaps between Pakistan-China's joint venture is the absence of adequate social and cultural communication between the people of both countries. The ongoing exchange programs that involve students, professionals and media practitioners from both sides have resulted in minimizing the gap over the period but it's not enough. With the expansion and advancement in these projects more can be done to build a strong link between the public of Pakistan and China (Hussain, 2017). There will be need for greater cooperation at cultural level between both states that reduces the alienation and communication gap between residents of Pakistan and China.

\section{WAY FORWARD: FROM STRATEGIC PARTNERSHIP TO STRATEGIC INTERDEPENDENCE}

Sino-Pakistan relationship has remained mutually rewarding despite challenges posed by the changing political and strategic dynamics. The strategic partnership has now reached a new height where both countries have become interdependent specifically after the initiation of CPEC and in the backdrop of US behaviour in ignoring Pakistan's contribution in the War on Terror (WoT) and using it as a scapegoat for its failed policies (Lee, 2016, p.11). Economic connectivity has become imperative in recent world affairs. With the changing nature of war, economic alliances and preponderance have gained immense significance. Pakistan lies at the crossroads of West, South and Central Asia and neighbours a rising global power. The deep-sea connectivity, maritime linkages, accessibility to warm waters, make Pakistan geostrategically pertinent to many countries especially major powers (Khetran, 2017). Now that Pakistan has eliminated much of terrorism through the country it is relatively more investment friendly. It is important to note that both countries should give due recognition to the fact that both are equally important for each other's strategic interests. China relies on Pakistan for its economic and strategic ambitions as much as Pakistan relies on China's military, economic and diplomatic support. 
With the US' pivoting to Asia and growing Indo-US nexus, it is evident that Pakistan and China need each other the most now. This does not however denote that either of the states will sabotage its relations with other partners. Pakistan cannot afford to infuriate US and Europe, nor will China ignore its economic ties with India. There is a delicate balance that has to be maintained. Both states share an understanding of each other's political and strategic compulsions which makes the bond resilient (Zeb, 2014). Pakistan's opening up to Russia, growing Indo-US nexus, China's BRI, Pakistan's strategic and economic vulnerability, situation in Afghanistan, cooperation at regional forums like Shanghai Cooperation Organization, transnational terrorism and most importantly Pakistan and China being neighbours, are all of the converging factors that intertwine China and Pakistan's national interests into "strategic interdependence".

While with the recent IMF conditions and Pakistan-US improving ties, Sino Pakistan relationship has faced a slight set-back but this interdependence is too deep to be shaken at such inconveniences. President Arif Alvi visited President Xi Jinping in March 2020 where President Xi reiterated that China will stay committed to its friendship with Pakistan no matter how international scenario might change. China is and will be standing firmly with Pakistan ("China Will Always Stand by Pakistan, Says President Xi”, 2020). China's lauding of Pakistan's anti-terrorism efforts and both states cooperation on the outbreak of COVID19 pandemic all add to indicate commitment of both states to their relationship. It is significant for Pakistan and China both to enhance their economic and people to people ties while keeping in view the intricacies of each other's interests with other partners. The balance is hard to maintain but that is the best option available. 


\section{REFERENCES}

BBC (2020, February 29). Afghan Conflict: US and Taliban Sign Deal to End 18Year War. [Vedio]. BBC News. from https://www.bbc.com/news/av/embed/p077kpwc/51689443.

Afridi, J., \& Bajoria, J. (2010, July 6). China-Pakistan Relations. Council on Foreign Relations. https://www.cfr.org/backgrounder/china-pakistan-relations

Ali, G. (2017). China-Pakistan Relations: A Historical Analysis. Karachi: Oxford University Press.

Azeemi, H. R. (2007). 55 Years of Pakistan-China Relationship. Pakistan Horizon, 60(2), 109-124.

Brahma, K. (2018). The Geo-Politics of China-Pakistan Economic Corridor (Unpublished Master's Thesis) Sikkim University. http://14.139.206.50:8080/jspui/bitstream/1/6115/1/Khargeswar\%20Brahma. pdf

Chandra, D. S. (2016). China-Pakistan Relations: Implications for India. Vij Books India Pvt Ltd.

Chaudhri, M. A. (1986). Strategic and Military Dimensions In Pakistan-China Relations. Pakistan Horizon, 39(4), 15-28.

China will always stand by Pakistan, says President Xi. (2020, March 18). Dawn. https://www.dawn.com/news/1541744.

Thomson Reuters (2007, January 20). Chronology-Main events in ChinesePakistani Relations.Reuters.https://www.reuters.com/article/us-pakistanchina-chro-idUSISL9262520061124 
Elizabeth, Economy. (2017, August). History with Chinese Characteristics: How China's Imagined Past Shapes Its Present. Foreign Affairs. https://www.foreignaffairs.com/reviews/review-essay/2017-06-13/historychinese-characteristics

Fazl-e-Haider, S. (2020, January 30). Is China set to play a Greater role in Afghanistan? Alaraby; The New Arab. https://english.alaraby.co.uk/english/indepth/2020/1/30/will-china-play-agreater-role-in-afghanistan

Faisal, M. (2018). Impact of Geo-Economics on Pak-China Strategic Relations. Strategic Studies. 38 (1). http://issi.org.pk/impact-of-geo-economics-on-pakchina-strategic-relations/.

Gopi. (2020, February 13). IMF asks Pakistan to cut Reliance on China. Social News XYZ. https://www.socialnews.xyz/2020/02/13/imf-asks-pakistan-to-cutreliance-on-china/

The Intel Brief. (2019, March 15). How Economic \& Political Tensions Impact the Sino-Pakistani Relationship. The Cipher Brief. https://www.thecipherbrief.com/column_article/how-economic-politicaltensions-impact-the-sino-pakistani-relationship.

How will the Belt and Road Initiative advance China's Interests? (2017, May 8). China Power: Unpacking the Complexity Rise, Center for Strategic and International Studies. https://chinapower.csis.org/china-belt-and-roadinitiative/.

Hussain, Z. (2017). The China-Pakistan Economic Corridor and The New Regional Geopolitics. Asie. Visions, 94. Policy Paper. French Institute of International Relations. https://www.ifri.org/en/publications/notes-de$\underline{\text { lifri/asie-visions/china-pakistan-economic-corridor-and-new-regional }}$

Ibrar, M., Mi, J., Rafiq, M., \& Karn, A. L. (2016). The China-Pakistan Economic Corridor: Security Challenges at a Geopolitical Crossroads. DEStech Transactions on Economics, Business and Management, (apme). 
Javaid, U., \& Javaid, R. (2016). Strengthening Geo-Strategic Bond of Pakistan and China Through Geo-Economic Configuration. Pakistan Economic and Social Review, 54(1), 123-142.

Khan, H. U. (2018). China Pakistan Economic Corridor (CPEC): Benefits for Pakistan and Comparison with Suez and Panama Canals. Naval Postgraduate School Monterey Ca Monterey United States.

Khetran, M. S. (2017). Economic Connectivity: Pakistan, China, West Asia and Central Asia. Journal of Institute of Strategic Studies, 4, 16.

Khursheed, A., Haider, S. K., Mustafa, F., \& Akhtar, A. (2019). China - Pakistan Economic Corridor: A Harbinger of Economic Prosperity and Regional Peace. Asian Journal of German and European Studies, 4(1), 7. https://doi.org/10.1186/s40856-019-0044-2

Lee, R. (2016). The Strategic Importance of Chinese-Pakistani Relations. Al Jazeera Centre for Studies.

Mahdi, N. (1986). Sino-Pakistan Relations: Historical Background. Pakistan Horizon, 39(4), 60-68.

Mahesar, P. A., Ghumro, A. K., Khuskh, G. M., \& Mahesar, A. H. (2016). Pakistan-China Relations: Thinking through an Indian lens. 3(3), 15.

Malik, A. R. (2017). The Pakistan-China Bilateral Trade: The Future Trajectory. 24.

Menhas, R., Mahmood, S., Tanchangya, P., Safdar, M. N., \& Hussain, S. (2019). Sustainable Development under Belt and Road Initiative: A Case Study of China-Pakistan Economic Corridor's Socio-Economic Impact on Pakistan. Sustainability, 11(21), 6143. https://doi.org/10.3390/su11216143

Pakistan-Hangor-Type 41 Yuan-class New Submarines. (2017, January 05). Global Security https://www.globalsecurity.org/military/world/pakistan/ssnew.htm 
Panganiban, A. V. (2017, May 28). No permanent friends or enemies. Inquirer.net. https://opinion.inquirer.net/104346/no-permanent-friends$\underline{\text { enemies }}$

Rahman, F. U. (2007). Pakistan; s Evolving Relations with China, Russia and Central Asia. Russia and Its Neighbors in Crisis, Slavic Eurasian Research Center, Hokkaido University, Japan. http://src-h. slav. hokudai. ac. jp/coe21/publish/no16_1_ses/11_rahman.pdf.

Sattar, H. (2015, March). China and Pakistan's All-Weather Friendship: The two countries enjoy remarkably enduring relations. The Diplomate. https://thediplomat.com/2015/03/china-and-pakistans-all-weather-friendship/

Siddiqi, H. A. (2020, April 7). Assessing Special Economic Zones of CPEC: Prospects for Pakistan. Pakistan Observer. https://pakobserver.net/assessingspecial-economic-zones-of-cpec-prospects-for-pakistan/

Siddique, Q. (2014). Deeper than the Indian Ocean? An Analysis of Pakistan-China Relations (No. 16; pp. 35-42). Centre for International and Strategic Analysis CISA. http://strategiskanalyse.no/Publikasjoner\%202014/2014-0227_SISA16_Sino-Pak_QS.pdf

Siddiqi, R. (2017). Prospects for Russia-Pakistan Rapprochement. Strategic Studies, 37(2), 58-73.

Small, A. (2015). The China Pakistan Axis: Asia's New Geopolitics. London: Hurst.

The Boundary Agreement Between China and Pakistan. (1963). https://people.unica.it/annamariabaldussi/files/2015/04/China-Pakistan1963.pdf

Toor, M. R. (2017). An Assessment of China-Pakistan Economic Corridor: Threats, prospects and implications. International Affairs and Global Strategy, 56. 
Torres, J. (2020, November 17). A guide to the Karakoram Highway-From Pakistan to China. Against the Compass. https://againstthecompass.com/en/karakoram-highway/.

Weinraub, B. (1974, October 14). Pakistani Presses U.S. for Arms. The New York Times. https://www.nytimes.com/1974/10/14/archives/pakistani-presses-usfor-arms-not-in-the-race.html

Zeb, R. (2014). Pakistan-China Relations: Where They Go from Here? Revista UNISCI Discussion Papers. (29), 45-58.

https://doi.org/10.5209/rev_UNIS.2012.n29.40659 